\title{
VÍNCULOS DE SENTIDOS: PUBLICIDADE, MARCAS E CONSUMO ALIMENTAR NA VIDA DE FAMÍLIAR PAULISTANA ${ }^{1}$
}

\author{
Meeting points: advertisement, brands and food consumption in São Paulo’s \\ family life
}

Eneus Trindade ${ }^{2}$

\section{Resumo}

O texto é parte dos resultados empíricos da pesquisa $A$ produção de sentido na recepção da publicidade e nas práticas de consumo de alimentos na cidade de São Paulo (financiada pelo $\mathrm{CNPq}$ ), tendo como objetivo compreender os vínculos de sentidos entre as marcas e as publicidades no consumo alimentar da vida doméstica de três famílias paulistanas. A metodologia dá-se por um olhar teórico que revela os tipos de vínculos entre a influência do fluxo da recepção de mensagens midiáticas das marcas e da publicidade de alimentos nas práticas culturais de consumo dos ambientes familiares investigados.

Palavras-chave: alimentação; publicidade; recepção; vínculos de sentidos; consumo.

\begin{abstract}
The text is part of the empirical results of the research for meaning production in the reception of advertising and practices of food consumption in the city of São Paulo (financed by $\mathrm{CNPq}$ ), aiming at understanding the links of meaning between brands and advertisements in food consumption of daily life of three families from São Paulo. The methodology is given by a theoretical look which reveals types of meeting points between the influence of the flow of the reception of media messages and advertising of brands in cultural practices of food consumption of familiar environments investigated.
\end{abstract}

Keywords: food; advertising; reception; meeting points; consumption.

\footnotetext{
1 Trabalho formulado com base nos trabalhos apresentados no GP Publicidade - Epistemologia e Linguagens do X Encontro dos Grupos de Pesquisa em Comunicação, evento componente do XXXIII Congresso Brasileiro de Ciências da Comunicação, Caxias do Sul - RS e no GT- Estudios da Recepción, durante X Congresso Latinoamericano de Investigadores de la Comunicación - ALAIC, realizado na Póntifíca Universidad Javeriana de Bogotá, Colômbia, no período de 22 a 24 de setembro de 2010.

${ }^{2}$ Professor Adjunto do PPGCOM e do Curso de Graduação em Publicidade e Propaganda da ECA-USP. Editor Responsável da Revista Signos do Consumo. Vice-Coordenador do Gesc3 - Grupo de Estudos Semióticos em Comunicação, Cultura e Consumo e Grupo Coletivo de Estudos em Estética, ambos cadastrados no CNPq/ECA/USP. E-mail: eneustrindade@usp.br.
} 
Vínculos de sentidos: publicidade, marcas e consumo alimentar na vida de famíliar paulistana

de Eneus Trindade

\section{Resumen}

El texto forma parte de los resultados empíricos de la búsqueda de la producción de sentido en la recepción de la publicidad y en las prácticas de consumo de alimentos en la ciudad de São Paulo (financiado por el CNPq), con el objetivo de comprender las relaciones de los significados entre las marcas y anuncios en consumo de alimentos de la vida doméstica de tres familias de São Paulo. La metodología está dada por una mirada teórica donde se percibe los tipos de vínculos entre la influencia de la recepción de mensajes de los medios y la publicidad de las marcas de alimentos en las prácticas culturales de consumo de los entornos familiares investigados.

Palabras clave: alimentos; publicidad; recepción; puntos de contacto; consumo.

\section{INTRODUÇÃO}

Este texto é parte dos resultados empíricos da pesquisa $A$ produção de sentido na recepção da publicidade e nas práticas de consumo de alimentos na cidade de São Paulo (financiada pelo CNPq), que busca compreender os vínculos de sentidos entre as marcas e as publicidades no consumo alimentar da vida doméstica de três famílias paulistanas e nos ambientes públicos da cidade. Aqui, daremos foco ao consumo alimentar doméstico (familiar) por meio de um olhar teórico que procura revelar os tipos de vínculos de sentidos entre a recepção ou a influência do fluxo da recepção de mensagens midiáticas das marcas e da publicidade de alimentos nas práticas culturais de consumo dos ambientes familiares investigados. O artigo demonstra que o lugar dos estudos da linguagem publicitária (da emissão à recepção) deve privilegiar a construção de modelos teóricos sobre os vínculos de sentidos.

Os vínculos de sentidos, como já explicado em outras oportunidades (TRINDADE, 2008b e 2009a), se estabelecem como situações de consumo ou pontos de contato (DI NALLO, 1999, p 201-216) e que, na nossa compreeesão, se estabelecem na relação da enunciação da recepção publicitária em seus fluxos (TRINDADE, 2008 a e b; PEIDRAS, 2006) com as práticas de consumo, como lugares de identificação dos processos de tranferências de significados do sistema produtivo dos alimentos, no caso deste estudo, para a vida dos indivíduos. Esse processo de transferência se dá por meio do sistema publicitário que auxilia nas construções dos sentidos simbólicos dos bens de 
Vínculos de sentidos: publicidade, marcas e consumo alimentar na vida de famíliar paulistana

de Eneus Trindade

consumo alimentares junto às vidas das pessoas, sugerindo práticas de consumo que, por sua vez, se trasnformam em práticas efetivas no cotidiano. Sobre esta discussão ver relações entre McCracken (2003, p. 99 -101), referentes aos rituais de consumo; e Poulain (2002, p.223), referente ao sistema de produção/consumo alimentar.

Quanto aos vínculos de sentidos, esclarecemos que eles podem ser definidos de dois modos:

O primeiro vínculo, o sígnico material: a marca/produto com seu mundo da publicidade torna-se o elo comum ou cronotópico entre o tempo e o espaço da marca e o tempo e o espaço dos consumidores-receptores. Ver (TRINDADE e BARBOSA, 2007, p.137-139). Neste caso, o consumo é operado por uma influência direta e indireta das mensagens publicitárias. Direta, pois os valores da publicidade geram identificação com o consumidor-receptor. Indireta, porque isso também depende de outros fatores ligados ao nível socioeconômico do sujeito, do seu repertório cultural - que influenciam suas decisões de compra.

O segundo vínculo, o sígnico-simbólico e se refere a algum tipo de influência da publicidade, que não se reverte no consumo de um bem (marca /produto ou serviço) específico, mas que se reverte na incorporação de um estilo de vida, de um modo de existência pragmática ou afetivo que o consumidor-receptor adota em seus comportamentos pelo consumo e que tomam para si como forma de manifestação de seus hábitos, o que por sua vez se converte em seus valores e visões de mundo. Isso logicamente ganha adaptações e variações conforme repertório cultural e nível socioeconômico dos sujeitos. (TRINDADE, 2009, p.8-9).

Os estudos dos vínculos de sentidos sobre o consumo alimentar nos tempos e espaços domésticos em concordância com os pressupostos da enunciação da recepção publicitária (TRINDADE, 2008 a) devem, portanto, mapear o que é da ordem dos vínculos sígnicos-materiais e dos vínculos sígnicos-simbólicos, a partir das representações dos rituais de consumo, observando a influência da mediação das marcas e da publicidade nesses processos.

Para verificação das dimensões propostas acima, ilustraremos nossa discussão com manifestções do estudo exploratório que realizamos em 2009 junto a três famílias. Contudo, não é nosso objetivo explorar novamente a descrição etnográfica que já realizamos, mas torna-se necessário o resgate da caracterização das famílias investigadas durante o trabalho de campo. Os aspectos descritivos da pesquisa encontram-se em Trindade e Moreira (2009). A classificação das famílias nos segmentos sociais (alta renda, renda média e baixa renda) seguiu os critérios sociodemográficos da Associação Brasileira das Empresas de Pesquisas ABEP. Interessa-nos, agora, oferecer ao leitor um conjunto mínimo de informações sobre o trabalho de campo que foi realizado. 
Vínculos de sentidos: publicidade, marcas e consumo alimentar na vida de famíliar paulistana

de Eneus Trindade

A família de alta renda é formada por um casal natural de São Paulo capital. Ele, bem sucedido profissionalmente, vive o segundo casamento com uma esposa mais jovem. Na classe média as entrevistas foram realizadas com três integrantes da família: a mãe e seus dois filhos. Os garotos eram adolescentes. A participação mais ativa durante as entrevistas foi da mãe e do filho mais novo, enquanto o filho mais velho se portava mais reservadamente. O pai da família optou por não dar depoimento devido à falta de disponibilidade de horários. Na família de baixa renda, as entrevistas foram realizadas com três dos quatros integrantes da família, na casa modesta onde residem: a mãe (idosa) que mora com um filho mais velho (professor de educação física da Rede Pública Estadual de São Paulo) e uma de suas irmãs, todos em idade adulta. (TRINDADE, 2009, p. 10-11).

Quanto ao material específico da pesquisa, que traz resultados sobre o consumo alimentar, cabe esclarecer que os vínculos de sentidos são abordados a partir dos dados percebidos pelas imagens fotográficas feitas nos ambientes observados (tempos e espaços) e pelos discursos dos membros das famílias (sujeitos) de cada segmento social investigado. Com base nestes critérios foram identificados os rituais de consumo pelas práticas de consumo manifestadas nas seguintes dimensões: alimentos e marcas identificados, rituais alimentares, influências midiáticas na alimentação, rituais de compras alimentares e marcas que mais gostam.

\section{VÍNCULOS DE SENTIDOS, IMAGENS DE ALIMENTOS E RITUAIS DE CONSUMO - FAMÍLIA DE ALTA RENDA}

De acordo com os registros das famílias, identificamos a presença de alguns produtos e marcas nos espaços dométicos visitados:

\section{Alimentos/Marcas}

Cereais: Pão de Forma Nutella®; Leites e Derivados: Requeijão Cremoso Light Danúbio®; Queijo Tipo Peti Suisse Polenguinho®; Leite Fermentado Yakult ${ }^{\circledR}$; Iogurte Paulista ${ }^{\circledR}$; Iogurte Activa Danone ${ }^{\circ}$; Margarina Qually® Queijo Minas Frescal Light Frescatino®; Leite Desnatado Paulista®; Leite de Soja Ades ${ }^{\circledR}$; Frutas: Suco (parece de laranja) na Jarra; Pêra e Nectarina; Açúcares: Refrigerante Lata e Garrafa 600ml (com água dentro); Coca-Cola Zero®; Refrigerante $\mathrm{H} 2 \mathrm{OH}$ Pepsi®; Doces tipo torta Holandesa porções individuais (sem visualização da marca); Outros: Pimenta Tabasco®; Água Mineral garrafa (1 litro) (sem visualização da marca).

\begin{tabular}{|c|c|c|}
\hline Espaço & Prática consumo/ritual & Vínculo \\
\hline Geladeira & Armazenamento/conservação & sígnico-material \\
\hline
\end{tabular}


Vínculos de sentidos: publicidade, marcas e consumo alimentar na vida de famíliar paulistana

de Eneus Trindade

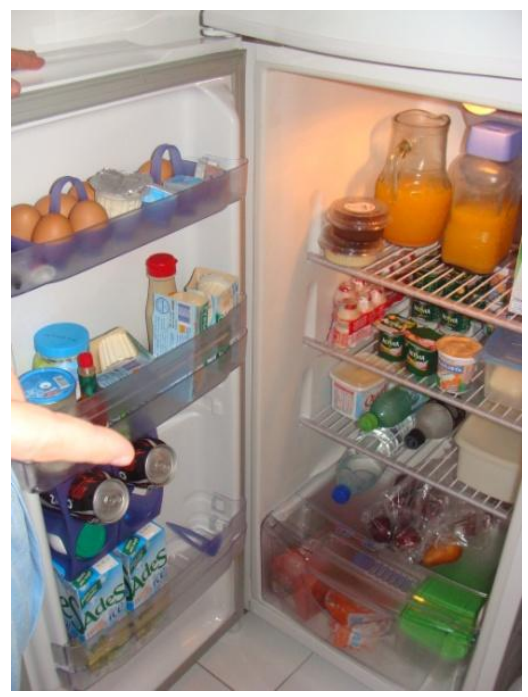

\section{Alimentos/Marcas}

Requeijão Cremoso Light Danúbio ${ }^{\circledR} ;$;izza Pizzaria Itália®; Sal Light Linea®; Pimenta do Reino Carmeno®; Temperos Diversos; Açúcar ( sem marca); Pizza Pizzaria Itália ${ }^{\circledR}$; Refrigerante Lata Coca-Cola Zero®

\begin{tabular}{|c|c|c|}
\hline Espaços & Prática consumo/ritual & Vínculo \\
\hline $\begin{array}{c}\text { Balcão cozinha, mesa } \\
\text { cozinha e fogão. }\end{array}$ & $\begin{array}{c}\text { Uso sugerido, preparo e cocção } \\
\text { Jantar e café da manhã }\end{array}$ & sígnico-material \\
\hline
\end{tabular}

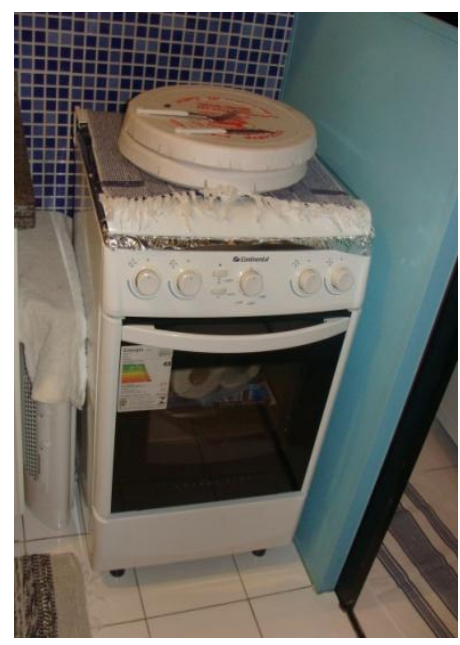

\section{Alimentos/marcas}

Cereais: Arroz Uncle Bens®; Aveia Quacker®; Açúcares: Adoçante (Sache) Finn®; Adoçante Líquido Zero Cal®; Achocolatado Nescau®; Gorduras: Maionese Helmanns®; Azeite Carbonel®; Legumes e Verduras: Ervilha Jurema®; Massa tomate Salsaretti®; Leites e Derivados: Creme de Leite Nestlé®; Outros: Sal Cisne®; Suco em Pó Clight ${ }^{\circledR}$; Chá Mate Leão®; Essências Frutas Arcolor $®$; Petisco para Cachorro.

\begin{tabular}{|c|c|c|}
\hline Espaços & Prática consumo/ritual & Vínculo \\
\hline Armários de cozinha & Armazenamento/ posse & sígnico-material \\
\hline
\end{tabular}


Vínculos de sentidos: publicidade, marcas e consumo alimentar na vida de famíliar paulistana

de Eneus Trindade

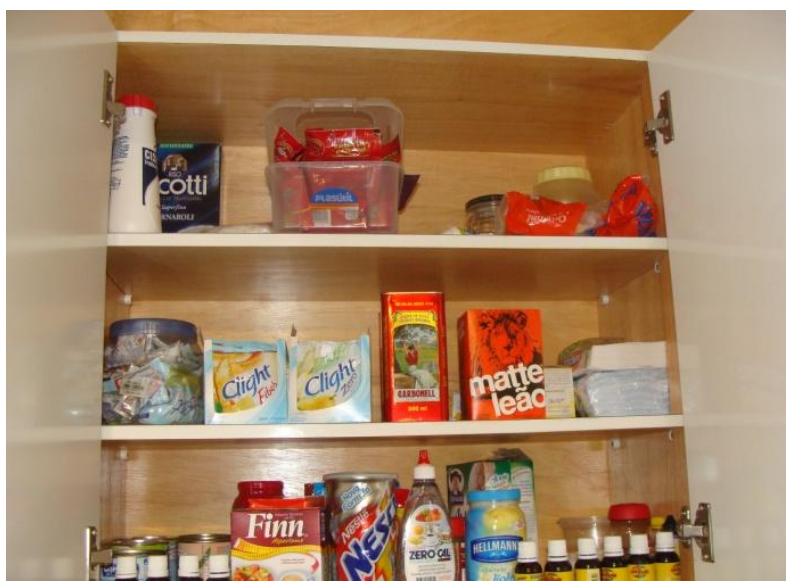

Os vínculos de sentidos aqui sugeridos pelas imagens registradas por meio de fotografias dos alimentos encontrados no lar dos entrevistados sugerem apenas uma ligação sígnica material. Por outro lado, a maioria das marcas encontradas são marcas que possuem constantes ações de publicidade nas mídias e de promoção nos pontos de vendas o que, certamente, dentro do universo simbólico da classe de alta renda aponta para a forte presença de vínculos sígnicos-simbólicos. Esse aspecto fica confirmado ao trabalharmos os discursos da família entrevistada.

\section{Vínculos de sentidos nos discursos sobre os rituais de consumo alimentar na família de alta renda}

\section{Rituais alimentares}

(Esposo) "Basicamente, acordo de manhã, faço um café da manhã... é pra nós, basicamente, pra P. (esposa)... só nós dois".

Entrevistador: Tomam café juntos?

Resposta: "Não porque que só tomo um gole de suco é..., eu não gosto de comer de manhã, então como eu não me alimento como deveria de manhã é, é basicamente pra ela que ela faz o café da manhã dela normal.”.

\section{Influências midiáticas na alimentação}

(Esposo) "Preparo o café com a televisão ligada".

(Esposo sobre a Revista Cláudia ${ }^{\circledR}$ e o Encarte) "Mas, tem um encarte que me interessa que eu gosto que é a parte culinária. Então tem uma revista com um encarte culinário todo mês que essa eu leio inteirinho... Mas isto é um hobbie".

(Esposo sobre a Revista Caras ${ }^{\circledR}$ e o Brinde) “... é uma revista totalmente fútil... sem necessidade que foi adquirida a assinatura porque ela trazia o brinde que me interessava. Que é a Caras®. Trazia um brinde de 23 livros de culinária, então, 23 livros muito bons de culinária. Então, eu fiz a assinatura. É uma revista fútil”.

(Esposo) "Por exemplo, esse suco que você (o entrevistador) tá tomando né?, da Ades®, Adês® (dúvida na pronúncia e a esposa o corrige) Pêra com menta. Se não tivesse a caixa na minha frente e você me perguntasse que suco é esse eu não saberia te dizer. Eu não sabia nem dizer. Por quê? Porque esse suco quem serviu, uma vez, foi o pai da P.(esposa), porque também, foi no supermercado... Ah tem uma coisa aqui de pêra com menta e comprou por 
Vínculos de sentidos: publicidade, marcas e consumo alimentar na vida de famíliar paulistana

causa da pêra com menta só pra saber como é que era. Caso contrário, você não fíca sabendo... E aí eu li numa revista dessas... Ah! Não!... Tem mais uma revista dessas, a Boa Forma ${ }^{\circledR}$ (se referindo ao começo da entrevista na qual listava as revistas que assina). Eu li numa Boa Forma ${ }^{\circledR}$, num dia desses no banheiro (local de hábito de leitura desta família que é recorrente durante a entrevista), eu li na Boa Forma ${ }^{\circledR}$ que esse produto (o Ades®) ele só vai ser fabricado no verão. Então ele começou a ser fabricado em novembro, outubro, final da primavera (dúvida ao recordar o período) e vai terminar em março. Eles não vão fabricar o ano inteiro. Então, é um produto sazonal... Então quando eu cheguei no supermercado.... (o entrevistador faz uma pergunta) ..... (Ele continua explicando) ...Pêra com Menta. Eles tem uma linha chamada Verão Mix, não é propaganda, é leitura de uma revista, Boa Forma ${ }^{\circledR}$, que era na parte de "menos calorias". Tava lá numa reportagem. Mais a reportagem dizia que era, esse produto, essa linha Verão Mix, é uma linha que tem um término; março acaba. ... Aí eu fui ao supermercado e quis comprar antes que acabasse. Entendeu?"

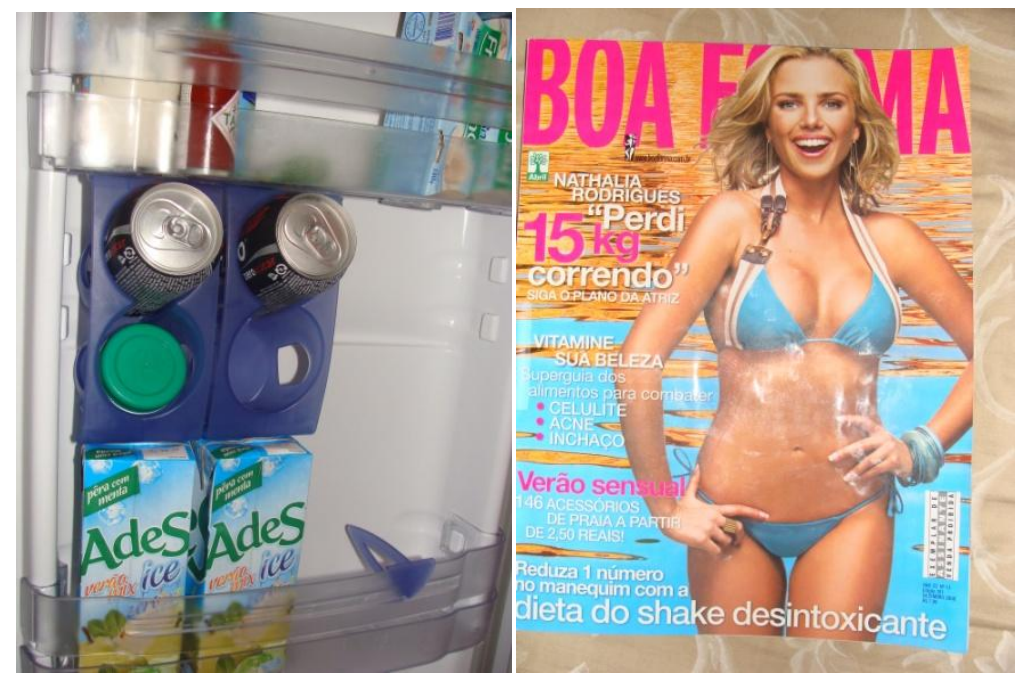

(A esposa sobre embalagens) "Meu pai mexe com embalagem então ele tá sempre ligado à embalagem nova. E tá sempre testando produto. Então, eu lembro desde que eu era pequena, abria a geladeira e tinha vai... pode comer ou não pode? ... Tá em teste ou não ainda".
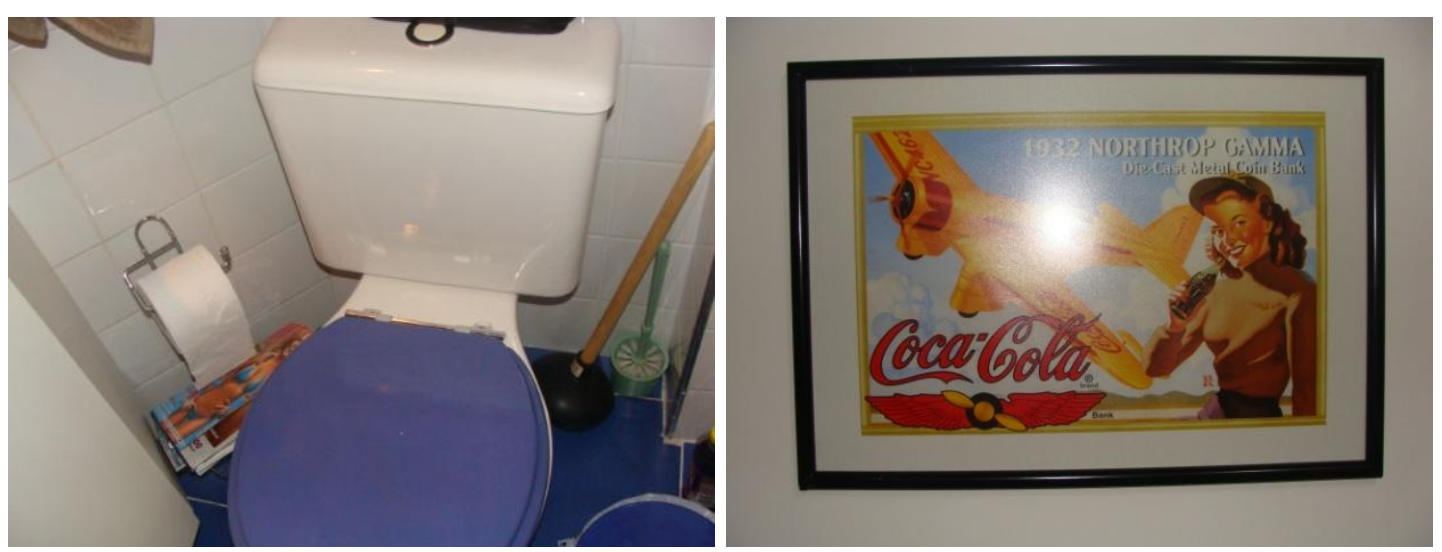

\section{Rituais de compras alimentares}

(Esposo) "Depende. Ultimamente eu tenho feito no Zafari ${ }^{\circledR}$ porque é muito perto. E porque ele tem uma quantidade de produtos muito grandes. Então assim, ele tem diversidade de produtos e o preço dele, na média, não é um preço exorbitante, na média". "Faço compra semanalmente. Eu fazia semanalmente. Agora eu tô fazendo compra pra quinze dias. Mas, o que eu compro também, aqui em São Paulo, é muito pra café da manhã e pequenos lanches de noite. Então, eu não compro, é..., comida pesada não compro muita coisa não... Porque, basicamente, a gente lancha a noite e porque no final de semana acabo viajando... Como são duas pessoas não tem porque você comprar muita comida em excesso. O que tem mais é sempre fruta, essas coisas, que aí ou eu vou na feira, ou eu compro no próprio Záfariß... Outro supermercado que eu utilizo, mas utilizo em casos mais urgentes, que é mais próximo ainda aqui da minha residência... É o Pão de Açúcar®. O Pão de Açúcar® eu utilizo de vez em quando... Porque no Pão de Açúcar® os preços são caros. Aí não vale. O custo benefício, não, vale. Vale assim..., puxa, esqueci de comprar, não 
Vínculos de sentidos: publicidade, marcas e consumo alimentar na vida de famíliar paulistana

de Eneus Trindade

tem nem uma sobremesa... Vai vir gente precisava comprar uma sobremesa... aí vai e compra um sorvete que é aqui do lado. Então, se vai do lado e compra."

...’Já comprei no Sonda®. O Sonda faz uns preços mais baratos. Mas, pra eu chegar ao Sonda® é bem mais longe."

"Em Peruíbe, basicamente, no Compre Bem ${ }^{\circledR}$ é basicamente açougue e feira. Eu compro fruta e carne... e carne aqui em SP eu também não compro em supermercado. Eu vou, também, em açougue.”

"Dia ruim, que é quinta feira, porque sexta, vamos para praia... Comprei um Paulista ${ }^{\circledR}$ (leite), porque não tinha Parmalat ${ }^{\circledR}$, Activa ${ }^{\circledR}$... Yakult ${ }^{\circledR}$. Yakult ${ }^{\circledR}$ tem toda semana... E por causa do intestino da P.(esposa), Polenguinho ${ }^{\circledR}$ serve tanto para a P. quanto pra cachorra. A cachorra gosta de Polenguinho®. Aí tem sempre uma coquinha (cocacola $\left.{ }^{\circledR}\right)$... Requeijão Danúbio®.” (Quinta- feira foi o dia da semana da visita do entrevistador).

\section{Marcas de alimentos que mais gostam}

( $1^{\text {a }}$ marca a ser falada pelo esposo) "Leite. Leite a gente gosta de comprar quando no supermercado tem leite da Parmalat ${ }^{\circledR}$. Aquele não o de caixinha, de garrafa plástica. Então, o leite Parmalat ${ }^{\circledR}$ é uma marca. Parmalat®”.

( $2^{\mathrm{a}}$ marca a ser falada pelo esposo) "Achocolatado vai. Outro produto. Achocolatado são dois produtos que eu gosto. Duas marcas totalmente diferentes. Um é o Nescau ${ }^{\circledR}$ ou é Ovomaltine ${ }^{\circledR}$. O Ovomaltine ${ }^{\circledR}$ eu acho que o gosto dele me lembra a infância. Além do que, o Ovomaltine ${ }^{\circledR}$, no passado, era MUITO, muito, muito, mais caro teoricamente do que qualquer outro achocolatado. Quando meus pais podiam, isso era uma vez ou outra, certo... Ou eu tomava na casa de algum amigo. Então, aquele gosto, e acho que gosto... gosto que ele é bom mesmo né, e ainda fica uns floquinhos né, que ficam derretendo né, pouco a pouco... Eu acho que aquele gosto é uma coisa do antigo e a parte da degustação né, salivar e gostoso, com a coisa que eu não podia comprar na época. Não podia ter acesso total na época. De vez em quando eu compro o Ovomaltine®. O Ovomaltine ${ }^{\circledR}$, às vezes eu deixo, inclusive, mais pra praia. E, normalmente, se eu for tomar, eu tomo Nescau® em casa aqui em São Paulo. É basicamente assim.”

( $3^{\text {a }}$ marca a ser falada com a lembrança da mulher) "o Azeite Carbonel® ${ }^{\circledR}$ O Azeite Carbonel® pra cozinhar lá na praia tem outros azeites. Azeites mais caros. Azeites diferentes. Esses azeites que vai coisa dentro e tal. Mas, no dia a dia azeite que eu gosto: o Carbonel®.

... "Então, assim, se for comprar leite condensado. Vai ser o leite moça ${ }^{\circledR}$ "

(Esposo) “... A mortadela... (a esposa ao fundo responde: ”a mortadela é Ceratti ${ }^{\circledR}$ ) Ceratti ${ }^{\circledR}$ ”... ”A salsicha Hans ${ }^{\circledR} \ldots$ Se você for pegar massa né. Eu prefiro Barilla®...”.

...Agora, panetone. Panetone, pra mim, só serve Bauduco®. Pode me comprar, assim,... Se me der um outro tipo de panetone daquela loja de chocolates... Como é que o nome dela? ... (a esposa responde ao fundo Copenhagen $\circledast$ )... Da Copenhagen ${ }^{\circledR}$, eu não quero. Que é cinco, seis vezes mais caro que o Bauduco®. Eu prefiro Bauduco® de passas lá, de frutas cristalizadas. Por quê? Por causa co gosto e do cheiro que ele tem. Ele é úmido. E lembra a infância.”

(Esposa) “Eu gosto do requeijão Danúbio® light, de Activia ${ }^{\circledR}$ ”.

O casal de alta renda aponta para uma rotina alimentar que ressalta o café da manhã. Os dois sujeitos não possuem os mesmo hábitos. O esposo come menos, por não ter fome pela manhã e ela toma o café "mais completo". Percebe-se que o almoço é feito fora de casa, pela condição de trabalho dos dois e à noite o casal prefere fazer lanches. Isso revela hábitos alimentares, do ponto de vista da nutrição, pouco suadáveis. Cabe destacar que o esposo sofre de problemas cardíovasculares.

Fica registrado no discurso do esposo que a alimentação como momento de encontro do casal, está resarvada aos finais de semana, quando eles se dirigem à casa de praia em Peruíbe, onde eles possuem maior conforto do que no apartamento no Bairro de Pompéia, endereço de classe média alta da cidade de São Paulo, onde residem 
Vínculos de sentidos: publicidade, marcas e consumo alimentar na vida de famíliar paulistana

durante a semana. Portanto, percebemos uma erosão da aliemtação doméstica nesta família no seu dia a dia.

Percebemos ainda, uma nítida influência midiática quanto à preferência por promoções referentes a publicações de culinária, pois o esposo gosta de cozinhar pratos diferentes com ingredientes especiais, busca novos sabores e é dado a experimentações gastronômicas, como se verifica no discurso da influência do pai de sua esposa e do anúncio da revista Boa Forma sobre o suco Ades sabor pêra com menta. Isso aponta para o aspecto multifatorial das decisões de compras na vida cotidiana, que nem sempre é totalmente definido pela publicidade.

De qualquer modo, o gosto pela gastronomia parece ser o vínculo sígnicosimbólico do estilo de vida do casal e os produtos tipo gourmet que possuem, como observamos na indicação de suas marcas favoritas, manifestam esse aspecto assim como a preferência por supermercados como Zafari e Pão de açúcar, próximos à residência do casal, o que também é indicador de status social elevado. É o poder comprar que indica posse, manifestado no discurso do casal pela qualidade na oferta dos produtos que as duas marcas varejistas de alimentos apresentam.

O consumo de alimentos neste núcleo familiar, ao menos no discurso e nas imagens registradas, parece ser moderado, pouco dado a desperdícios. Com uma alimentação mais funcional e prática durante a semana, não necessariamente saudável, com compras quinzenais. Os sabores diferentes e o prazer de comer ficam direcionados para residência de praia do casal, onde lá exercem plenamente os vínculos sígnicossimbólicos de seu estilo de vida, pois muitas das marcas preferidas do casal parecem construir um vínculo afetivo com o sentido de suas exitências.

\section{VÍNCULOS DE SENTIDOS, IMAGENS DE ALIMENTOS E RITUAIS DE CONSUMO - FAMÍLIA DE RENDA MÉDIA}

\footnotetext{
Alimentos/Marcas

Leites e Derivados: Requeijão Fazenda®; Leite Qualitá®; Açúcares: Geléia (sem visualização de marca); Refrigerante (sem visualização de marca); Gorduras: Maionese Arisco®; Margarina Delíciaß; Outros: Shoyu Sakura ${ }^{\circledR}$; Saches de Catchup; Catchup (sem visualização de marca); Refoga (sem visualização de marca); Vinagre (sem visualização de marca); Hambúrguer Extra®; Chiquenitos DaGranja ${ }^{\circledR}$
} 
Vínculos de sentidos: publicidade, marcas e consumo alimentar na vida de famíliar paulistana
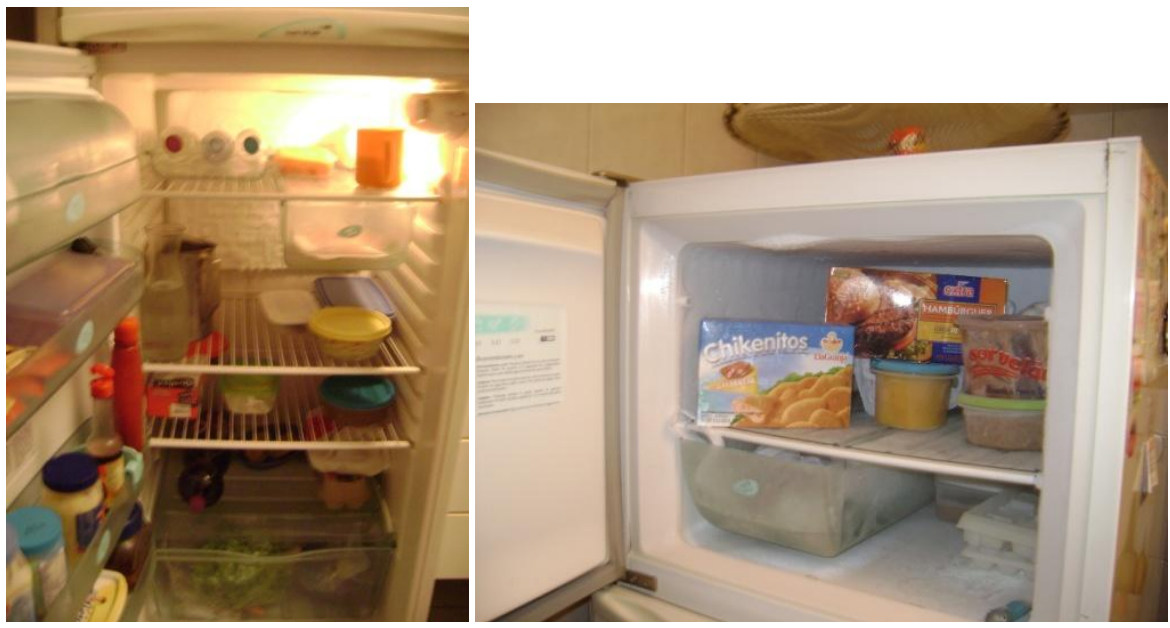

\begin{tabular}{|c|c|c|}
\hline Espaço & Prática consumo/ritual & Vínculo \\
\hline Geladeira & $\begin{array}{c}\text { Armazenamento/conservação/ } \\
\text { posse }\end{array}$ & sígnico-material \\
\hline
\end{tabular}

\section{Alimentos/Marcas}

Cereais: Biscoito Maria (sem visualização de marca); Macarrão Renata®; Pipoca Microondas (sem visualização de marca); Macarrão Instantâneo (sem visualização de marca); Amido de Milho Quero®; Açúcares: Açúcar Refinado União® ; Açúcar Refinado (sem visualização de marca); Gorduras: Óleo de Soja Lisa®; Óleo de Soja Soya ${ }^{\circledR}$; Legumes e Verduras: Massa tomate (sem visualização de marca); Leites e Derivados:Leite Semi-desnatado Nilza ${ }^{\circ}$; Leite Ninho Nestléß; Carnes: Filé de sardinha (sem visualização de marca); Outros:Sopa em Pó (sem visualização de marca); Xarope de Milho Yoki®; Leite Integral Qualitá®.

\begin{tabular}{|c|c|c|}
\hline Espaço & Prática consumo/ritual & Vínculo \\
\hline Armário/dispensa & $\begin{array}{c}\text { Armazenamento/conservação/ } \\
\text { posse }\end{array}$ & sígnico-material \\
\hline
\end{tabular}

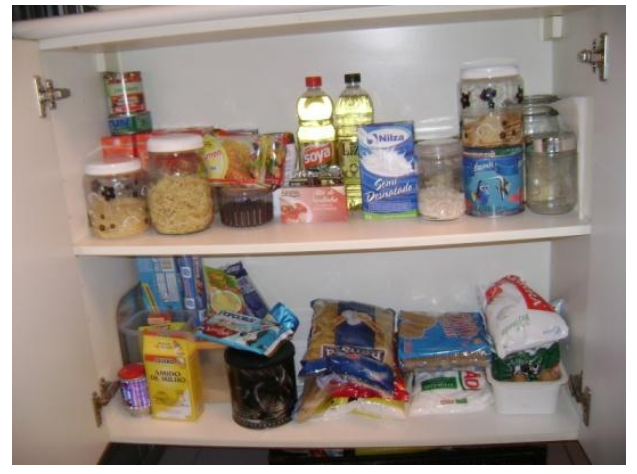

Pelos registros das imagens, há uma tendência ao consumo de marcas de alimentos menos conhecidas, populares, ou ainda, o uso de marcas próprias de varejistas, a exemplo da marca Qualitá (Grupo Pão de Açúcar), Hamburguer Extra. Essa opção aponta para um consumo, em seus rituais de compra, que se preocupa com a rentabilidade das compras de uma típica família de classe média da Zona Norte de São Paulo, aspecto este que se confirma nos discursos da mãe desta família. Percebemos também uma opção de alimentação que certamente inclui lanches para os adolescentes 
Vínculos de sentidos: publicidade, marcas e consumo alimentar na vida de famíliar paulistana

da casa indicada pela presença de catchup, de hamburgueres e chiquenitos. Os vínculos sígnicos-materiais aqui identificados não apontam para relações de vínculos sígnicossimbólicos entre as marcas e publicidade de alimentos e o estilo de vida dos moradores do apartamento onde a família reside. Talvez esses vínculos se dêem mais fortemente em outro aspecto da vida material. Contudo, pelas imagens registradas há uma adequação entre o perfil socioeconômico e o padrão de consumo apresentado visualmente nas imagens registradas.

\title{
Vínculos de sentidos nos discursos sobre os rituais de consumo alimentar na família de renda média
}

\author{
Rituais alimentares
}

(Mãe) “As refeições da família geralmente são conforme os horários de cada um. Todos têm horários diferentes. Minha única obrigação é deixar o almoço pronto, e cada um se serve na hora em que chegar em casa. Apenas C.S (pai), não almoça em casa... Gosta de variar o cardápio, mas não faço muitos pratos. Normalemente são três ou quatro porções diferentes, incluindo a carne e sempre tento fazer algo do agrado dos meninos, como batata frita ou nhoque."

(Mãe) “O café da manhã geralmente é rápido demais, cada um separa um copo de leite com achocolatado e uma banana, ou pão amanteigado, e já sai correndo para as obrigações. Quem toma café da manhã com mais calma é C.S. (pai), que chega um pouco mais tarde no trabalho que eu e os meninos no colégio... O jantar, sempre é alguma coisa do almoço misturado com uma pequena novidade... É quando todo mundo se junta. Mas dependendo do dia da semana, C.S (pai) participa de uma Igreja Evangélica, e em algumas noites ele só volta depois do jantar.

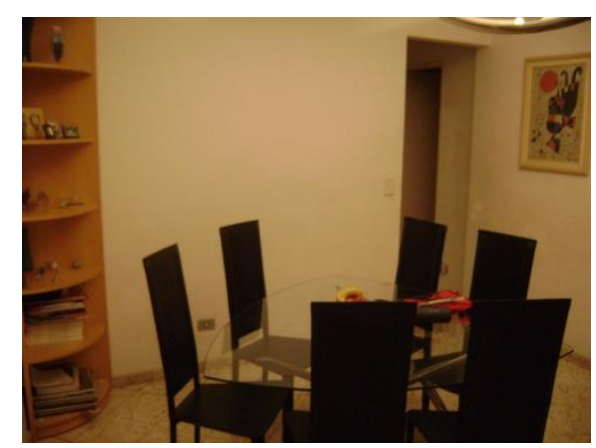

(Mãe) Uma atividade doméstica que ela mantém como diversão - diz ela, orgulhosa - "é saber cozinhar, principalmente doces. Aqui, todo mundo gosta, então eu sempre faço". A dona da casa gosta de experimentar receitas novas nos fins de semana, mas nada muito inovador, pois tem medo de estragar ingredientes.

\section{Rituais de compra alimentares}

(Mãe) "Prefiro fazer compras no supermercado ECON, próximo ao meu prédio, e chego a ir duas vezes por mês no supermercado. Também freqüento o Pão de Açúcar, mas com menor assiduidade e somente quando quero produtos mais específicos, como carnes ou vinhos. Para comprar frutas, verduras e legumes, prefire ir às feiras-livres que acontecem no bairro. Nas proximidades do prédio, ocorre uma às quartas e aos sábados. Gosto de ir lá porque encontro sempre alguma vizinha conhecida e acabamos fazendo compras juntas."

"Depois que foi inaugurado um novo shopping na proximidade do prédio fiquei curiosa para ir ao supermercado. Já ouvi falar desse supermercado e vi algumas propagandas, fiquei com vontade de ir lá, mas ainda não tive tempo".

Marcas de alimentos que gostam mais 
Vínculos de sentidos: publicidade, marcas e consumo alimentar na vida de famíliar paulistana

de Eneus Trindade

"Tenho sempre as mesmas marcas na cabeça no supermercado, mas gosto de experimentar... Coca-Cola.. Passatempo (bolachas)... Nescau... Aurora (carnes em geral)... Divella (massas de preparo rápido).... Coqueiro (atum enlatado). Tio João (arroz),. Brahma, Paulista e Elegê (marcas de leite), Pilão (café). Ninho (leite em pó),. Leite Moça (leite condensado)."

\section{Influências midiáticas na alimentação}

\footnotetext{
"Gosto de receber encartes de supermercados e grandes lojas para poder fazer comparativos de preços. Anoto do lado (no encarte) os preços, e vou ao supermercado que promete cobrir os preços, e assim consigo descontos em vários artigos comprados. Como eu ia conseguir saber de promoções e preços se não fossem as propagandas?”.
}

Parece-nos que o consumo constante de produtos e a intenção de experimentar coisas novas têm um significado (eventual) para o momento de compras da família. Além disso, fica patente a opção por escolhas mais econômicas. O supermercado preferido da dona da casa é o ECON, uma rede popular de varejo de bairros. Junto a isso, constatamos que a midiatização da publicidade, na opinião da mãe entrevistada, é fundamental para orientar suas compras, pois visando economizar nas despesas, ela sempre procura as opções mais em conta e compara preços.

A responsável da família é também a responsável pela compra e preparo dos alimentos da casa. Sua ação familiar dá o tom da alimentação que, em termos de rituais gregários ainda possui o momento do jantar como um tempo especial da família, quase todos os dias, exceto pela ausência do Pai em um dia na semana, quando este vai à Igreja. Este comportamento não se verifica na classe anterior.

As marcas preferidas da dona da casa indicam um gosto alimentar comum e apontam para um consumo ordinário dado a poucas inovações, como o discurso revela. Esta família não vê na alimentação um lugar privilegiado para manifestar seus vínculos sígnicos-simbólicos, que talvez sejam mais evidentes em outros setores da vida material.

A alimentação da classe média observada se dá por vínculos sígnicos materias que operacionalizam a alimentação no dia a dia. Contudo, na idealização de mulher/mãe, fica um dado do estilo de vida tradiconal da mãe de classe média que se refere ao ato de preparar doces, de vez em quando, para agradar os familiares. Todavia, as marcas e a publicidade não parecem ser tão fortemente constitutivas desse repertório simbólico.

4. VÍNCULOS DE SENTIDOS, IMAGENS DE ALIMENTOS E RITUAIS DE CONSUMO - FAMÍLIA DE BAIXA RENDA 
Vínculos de sentidos: publicidade, marcas e consumo alimentar na vida de famíliar paulistana

de Eneus Trindade

Alimentos/Marcas

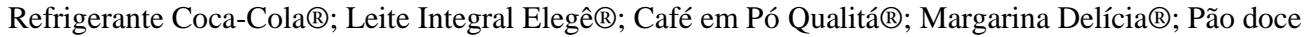
Sonda®; Pão; Pudim de Pão (caseiro).

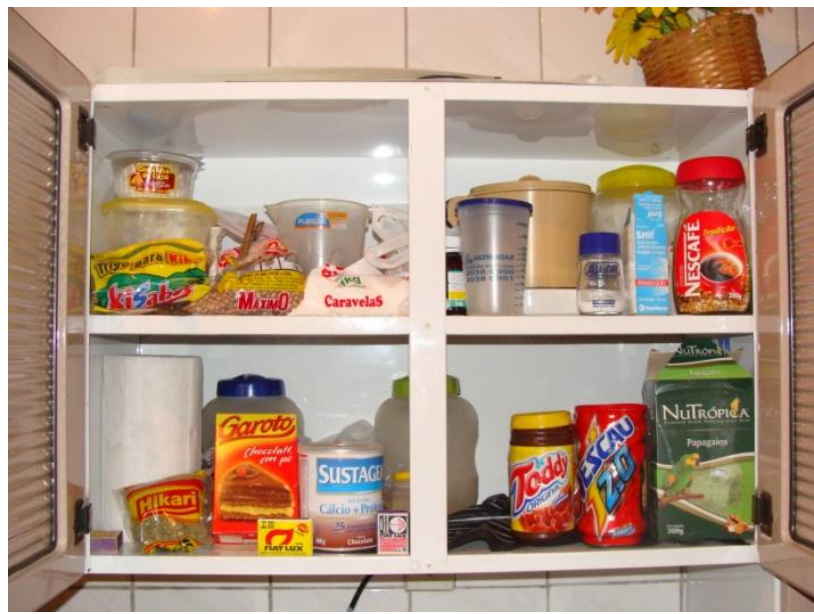

\begin{tabular}{|c|c|c|}
\hline Espaço & Prática consumo/ritual & Vínculo \\
\hline Cozinha & $\begin{array}{c}\text { Usos alimentares - mesa do } \\
\text { lanche/café da tarde }\end{array}$ & $\begin{array}{c}\text { sígnico-material e } \\
\text { sígnico-simbólico }\end{array}$ \\
\hline
\end{tabular}
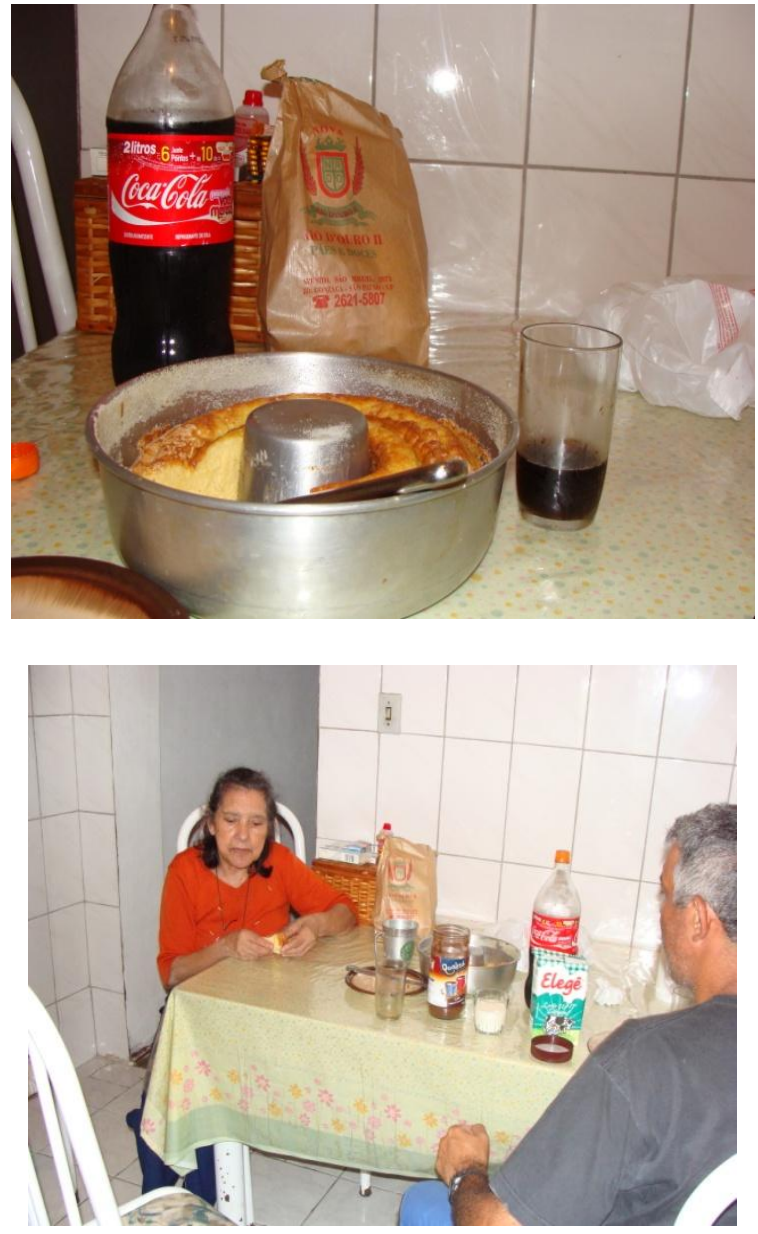
Vínculos de sentidos: publicidade, marcas e consumo alimentar na vida de famíliar paulistana

de Eneus Trindade

\section{Alimentos/Marcas}

Leites e Derivados: Leite Integral Elegê®; Margarina Delícia®; Leite Condensado (Acho que é Extra®); Leite Ninho Nestlé ${ }^{\circledR}$ (em cima da geladeira); Gorduras: Maionese Lisa®; Gordura vegetal hidrogenada Primor®; Açucar: Adoçante Zero Cal®; Suco em pó Tang®; Refrigerante Coca-Cola®; Outros: Catchup Extra®; Catchup sache Junior®; Caldo de Carne Arisco®; Fermento químico Pó Royal@; Farinha Láctea Nestléß.

\begin{tabular}{|c|c|c|}
\hline Espaço & Prática consumo/ritual & Vínculo \\
\hline Geladeira & Armazenamento /conservação & sígnico-material \\
\hline
\end{tabular}

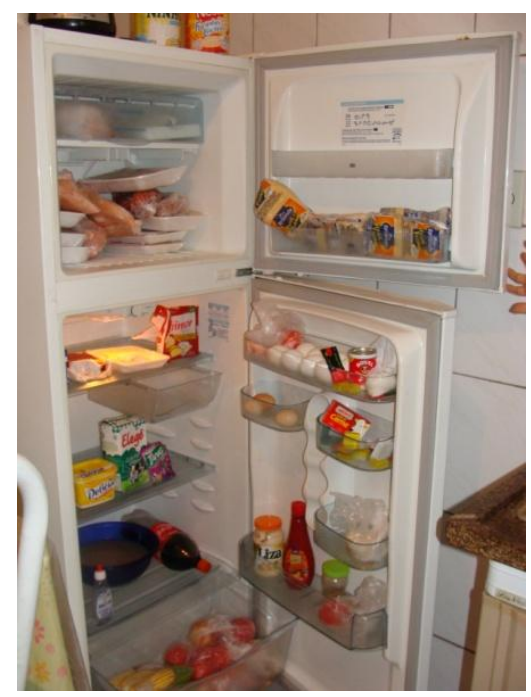

\section{Alimentos/Marcas}

Açúcar refinado Caravelas®; Feijão Máximo®; Lentilha Hiraki®; Sal (realça sabor) Ajinomoto®; Achocolatados: Toddy®; Nescau ${ }^{\circledR}$; e Garoto®; Suplemento Sustage ${ }^{\circledR}$; Trigo para quibe Kisabor ${ }^{\circledR}$.

\begin{tabular}{|c|c|c|}
\hline Espaço & Prática consumo/ritual & Vínculo \\
\hline Armário & Armazenamento /posse & sígnico-material \\
\hline
\end{tabular}

\section{Alimentos/Marcas}

Cereais: Arroz Tio João®; Biscoito recheado de goiaba Bauducco®; Macarrão instantâneo Nissin®; Biscoito Recheado Adria®; Biscoito maisena Marilan ${ }^{\circledR} ;$ Milho de pipoca Yoki®; Pipoca microondas Yoki®; Pó bolo Dona Benta ${ }^{\circledR}$; Farofa pronta Yoki ${ }^{\circledR} ;$ Macarrão Adria ${ }^{\circledR} ;$ Farinha de trigo Dona Benta®; Aveia Extra ${ }^{\circledR} ;$ Farinha de mandioca Pantera®; Amido de milho Maizena®; Fubá em flocos Yoki®; Fubá Yoki®; Milharina Quacker®; Milho verde Quero®; Leite e Derivados: Leite integral Elegê®;Leite condensado Itambé®; Carnes: Sardinha Coqueiro; Açúcar: Açúcar União®; Achocolatado Nescau Nestlé®; Gelatina Sol®; Leguminosas:Feijão Máximo®; Ervilha Extra®; Gordura: Óleo Perdigão; Legumes e Verduras: Molho tomate Salsaretti®; Massa tomate Tomatino®; Outros: Café em pó Qualitá®; Fermento químico Pó Royal®.

\begin{tabular}{|c|c|c|}
\hline Espaço & Prática consumo/ritual & Vínculo \\
\hline Dispensa & Armazenamento / acúmulo & sígnico-material \\
\hline
\end{tabular}




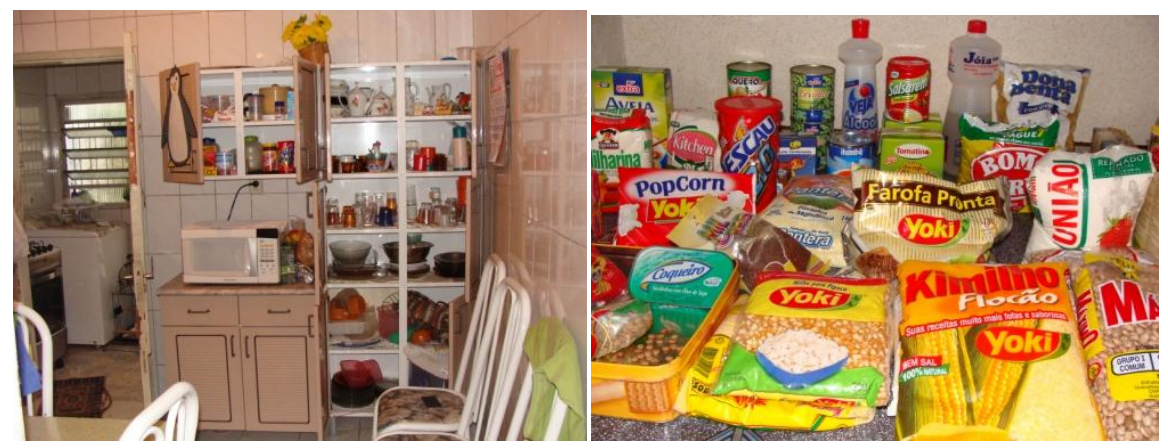

As imagens capturadas dos alimentos da família mostram opções por marcas populares, tradicionais e apresentam algumas marcas próprias que certamente foram escolhidas para otimizar o orçamento familiar nas compras dos alimentos. O que de certa forma se assemelha a classe média, a não ser pelo fato de observarmos uma quantidade de comida, que foi a maior entre as três famílias entrevistadas. A casa simples situada em bairro da zona Leste de São Paulo apresenta uma dispensa para armazenar alimentos, além do armário de cozinha e da geladeria. Também percebemos algumas frutas frescas em meio a produtos de limpeza. Fatos estes que também não haviam sido verificados nas outras casas.

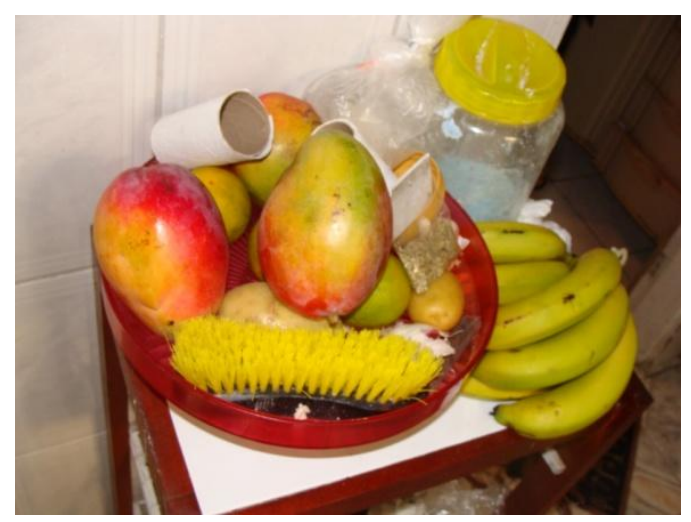

As informações da observação levam a crer na preocupação com a estocagem de alimento, seguindo uma lógica a semelhante aos períodos históricos de escassez alimentar, que nesta classe se aplica em função do baixo rendimetno da família. Isso se confirma, ao observamos as ricas informações discursivas dos sujeitos investigados.

\section{Vínculos de sentidos nos discursos sobre os rituais de consumo alimentar na família de baixa renda}


Vínculos de sentidos: publicidade, marcas e consumo alimentar na vida de famíliar paulistana

de Eneus Trindade

\section{Rituais Alimentares}

O filho mais velho (Professor da Rede Estadual de São Paulo de Educação Física)

Café da Manhã - "Café com leite pão e manteiga. Ou de vez em quando um pedaço de queijo magro... queijo branco... que mais... normalmente sozinho e ouvindo rádio"

Almoço - "É o arroz, feijão o basicão, e varia um pouco de salada. A mistura foi diminuindo os pedaços. Ah, porque você não tá com fome? Não. Porque eu to comendo muito. Eu acho que posso comer menos pra ficar menos gordo. Porque eu já to engordando. Não quero ficar gordo mais. Não quero. Eu quero perder peso eu to diminuindo a quantidade de mistura. Além de ser cara e tá me fazendo mal. Então são duas coisas que eu coloquei na mente, he he".

A mistura - "Carne, às vezes é lingüiça, às vezes é até um pedaçinho de porco, que eu gosto de porco... como às vezes sozinho e ouvindo rádio" (risos)...

A mesma comida para ele e para mãe que comem em horários diferentes (nunca bate).

Café da tarde - "Café da tarde quando estou em casa. Café, leite, café com leite, pão... Café tradicional de vez em quando rola um bolo, rola uma coisinha que é diferente... uma bolacha. Mas, tô diminuindo.

Entrevistador: Por falta de dinheiro?

Não. Porque tem muita caloria e não tá me ajudando. Eu preciso cortar essas coisas”.

Jantar - "Arroz, feijão... do almoço. Basicamente a mesma coisa. O que eu comi no almoço eu como da janta".

(A Mãe) "Eu acordo sete horas. Tomo café... tomo às vezes com o meu filho"

Café da Manhã - "Pão, café, queijo, um pedacinho, às vezes. Não é todo dia. Café com leite e... só".

Almoço - "O almoço é meio dia, onze meia, por aí". "Arroz, feijão, carne, uma fruta, às vezes verdura né?... tomate, salada e só."

Jantar - “Às vezes janta, às vezes...”.

\section{Rituais de compras alimentares}

O filho mais velho (Professor da Rede Estadual de São Paulo de Educação Física)

"Ultimamente tamo indo no Extra ${ }^{\circledR}$. Eu acho que as coisas também são muito baratas... então em relação aos outros supermercados pequenos tá tudo equivalente estão aumentando os produtos. Então, de um mercado para o outro a diferença é mínima a não ser dos atacadistas né? Que você pode comprar um volume maior e só. Por que... Tá muito cara as coisas! Muito cara."

"E o grande desafio do pessoal da área da publicidade é saber quanto o que brasileiro tem pra gastar a cada mês. Que cada mês que passa no mercado vai dinheiro, 30, 40, 30 40, 45 e cada vez que ele for lá comprar dá pra comprar menas coisas...".

“O Extra ${ }^{\circledR}$... O Carrefour ${ }^{\circledR}$ é caro... O Carrefour tá super caro, né. Tem o Carrefour tem o Compre Bem ${ }^{\circledR}$ que é caro também ...

“Uma vez por mês” faço a compra “...

"Porque que eu vou comprar internet eu vou gastar mais eu vou comprar comida ... Então, você troca os valores... Eu pelo menos sou assim".

\section{(Z. A Filha)}

"Eu que faço o supermercado pra minha mãe. Porque eles aqui eles não tem carro. E aí fíca difícil ir no supermercado fazer as compras do mês né. E ...como só mora ela e o meu irmão indo uma vez por mês é já é o suficiente né. Depois vai assim, durante a semana na feira, tal". 
Vínculos de sentidos: publicidade, marcas e consumo alimentar na vida de famíliar paulistana

de Eneus Trindade

"Normalmente no supermercado eu vou com ela pra ela até sair um pouquinho de casa. E tal, ela anda devagarzinho nos corredores. Então, eu sei mais ou menos tudo que precisa e tudo o que eu vou pegar.

"Eu já vou com uma lista... Mas... geralmente eu até faço uma lista, mas às vezes nem pego porque já gravo, já sei o que precisa".

"A grana aqui é um pouco curta, então eu vou nas promoções né. Tem lógico, a gente tem as marcas que a gente mais gosta. Mas se tiver mais barato e é mais ou menos semelhante a qualidade você vai pela promoção".

(Sobre a escolha do supermercado)... "É sempre o mesmo. Porque é um hipermercado, o Extra ${ }^{\circledR}$ que é aqui perto, que é grande e tem uns preços bons então já se encontra de tudo então a gente faz lá mesmo".

...”O supermercado que eu faço, na minha casa é outro muitas vezes eu trago o que tá em promoção de lá pra cá também, o Sonda ${ }^{\prime}$ ".

\section{Marcas de alimentos que mais gostam}

O filho mais velho (Professor da Rede Estadual de São Paulo de Educação Física)

"Nescau ${ }^{\circledR}$, produto da Nescau, chocolate da Nescau... o pó". "Nescafé®”. Leite tem o longa vida, o paulista®. Eu acho legal, gostoso. "Eu gosto e admiro... Mas, não é marca do feijão... Puxa vida! Complicado. Meu Deus!"

"É gostar, tipo assim... Como muito produtos são calóricos como é que sejam gostosos... é que você vai eliminando, entendeu, não é comendo, entendeu. Esta é a dificuldade. Por exemplo, tudo é enlatado. Tem coisa muito saborosa. A própria salsicha, a própria lingüiça. Mais são, são muito calóricas. Picanha, carne seca. Come tudo moderadamente. ... Aurora ${ }^{\circledR}$... "Carne não tem marca”...

"Pó Royal®, por exemplo, é um fermento que a gente sempre compra desta marca".

"Maisena não tem como a gente sempre compra a Maisena ${ }^{\circledR}$. É Maisena mesmo né? O amido de milho da marca Maisena®".

"Leite a gente compra de caixinha, mas é o da promoção também. O que tiver mais em conta a gente pega."

"Óleo também é sempre, a gente sempre compra o Lisa®".

"O arroz a gente compra ou o Tio João ${ }^{\circledR}$ ou Prato Fino® ou Camil®. Só esses três a gente pega. Que também tem muitas promoções, mas eu acho que arroz tem que pelo menos ficar um pouco soltinho. E esses três, um destes três, o que tiver na promoção a gente sempre pega".

\section{Influências midiáticas na alimentação}

(O filho mais velho - Professor da Rede Estadual de São Paulo de Educação Física)

“... a propaganda ela mente muito"... "propaganda de vitaminas é mentira. Vitamina comprada por 80 reais, 50 reais o e tem Vitamina de A a Z. Mentira! Pra por todos estes produtos (atributos), o produto devia custar 300 reais, no mínimo. Pra ter o conteúdo, realmente do produto. È mentira. Já foi comprovado isso. Eles venderam na cara dura. Porque tem cara mandando ver. Tem cara pagando por fora pra mostrar isso.”

Entrevistador: "Você lembra que marca é essa de A a Z?"

Resposta: "É o Centrum ${ }^{\circledR}$ né? Centrum ${ }^{\circledR}$ né. Que tem de A a Z. Então, essa propaganda é mentira, meu! Isto tem que valer uma nota pra valer aquilo lá."

Gatorade ${ }^{\circledR}$

“... O gatorade ${ }^{\circledR}$, né... rico em sais minerais... mentira. Tem pouquíssima quantidades de sais minerais. Se você colocar açúcar, sal e misturar e colocar uma pitada de limão e tomar é a mesma coisa. É mentira. Eles pagaram uma fortuna na época pra abafar.

"Então, a televisão é comprada. É comprada para enganar o povo... A televisão ganha por fora". 

paulistana

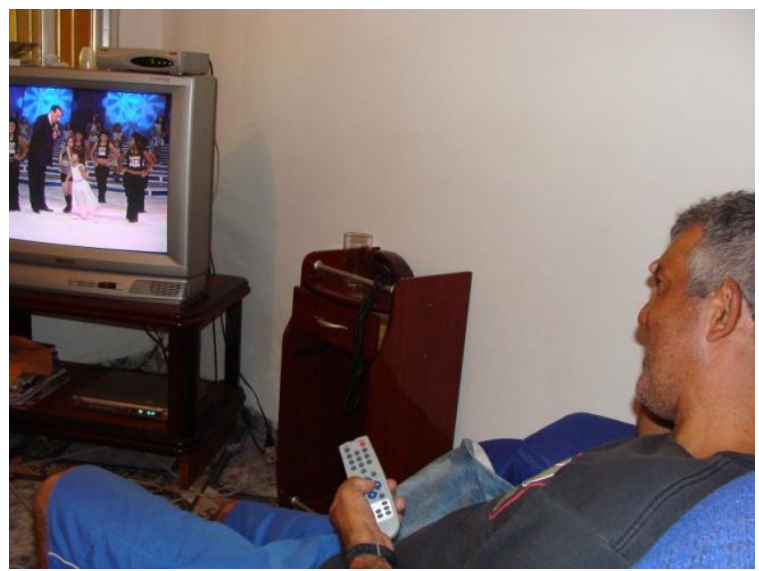

"O cara que faz uma propaganda bem feita ele tem crédito. Pode demorar, mas vai permanecer"...

Pamonha

A entrevista é interrompida (enquanto discutiam a propaganda do Rexona® ou Axé®, pois o entrevistado tinha dúvida quanto à marca do desodorante) por conta de um carro de pamonha ao fundo.

"Pamonha quentinha... Venha conferir... Alegria da garotada. As deliciosas pamonhas. Pamonhas quentinhas. Atenção fregueses e Atenção garotada..."

O que inicia a discussão sobre carros de som e venda de produtos

Entrevistador: "Você já chegou a comprar alguma coisa dos carros que passam assim?"

Resposta: "Comprei o que: sorvete, não hoje. Pão. Tinha pão, pamonha já cheguei a comprar "pamonha do milho verde". Comprava sim, hoje não. Quando era mais novo atraía".

Ações positivas de promoção e publicidade

"O selinho da margarina, ou margarina,... ah... nos potinhos de produto. Era 20\% era revertido pras casas tal. Isto dá um chamativo. Querendo ou não querendo. Poderia fazer mais coisas né?"

"Pote de margarina, por exemplo, não lembro... O selinho... Eu comprei... O gosto dá no mesmo. A marca fugiu, fugiu... Vi na propaganda foi na televisão. Passou na televisão primeiro. Aí eu achei super legal”.

"Por exemplo, o ano que vem vai ter empresa querendo entrar no futebol feminino. Ainda tá no começo. Tem uma marca de vinho que já ta comprando pra passar o campeonato paulista, por exemplo. Pô, se fizer isso com certeza o público feminino vai comprar bastante produto mesmo, pra manter o futebol feminino. Se eles jogar o foco... ele não tem noção quantas pessoas gostam de futebol feminino. Não tem noção. Se eles soubessem, na Rede Minas (emissora de Tevê) quando passa qualquer jogo de futebol feminino tava dando 8 poucos de audiência".

(a Publicidade) “... ela te mostra a gama de coisas que tá lançada aí né... De repente você fíca até com vontade até de experimentar".

"Às vezes tá um pouco cara. Mas, você experimentou uma vez... você... se tiver condição de comprar novamente você vai lá e compra. Mas se não Já experimentou uma vez já é suficiente. Já comeu já matou a vontade. Mais ou menos assim".

"Negativo que ela faz com que você às vezes queira consumir coisas que não tem condições né... "então você acaba forçando uma barra às vezes pela vontade de ter ou de comer determinada coisa que passa na propaganda"

"Por exemplo, minha mãe gosta muito de panetone. Ela adora panetone. Lógico que a qualidade do panetone Bauduco®, que é de uma marca muito boa. Passa o ano sem comprar um que a qualidade é legal, gostoso. E aí os demais cafés, aí você mantém com um de qualidade, ou de fabricação própria de supermercado ou de uma marca mais inferior com preço mais baixo, mas pra não deixar de ter o panetone que ela gosta. Mas, pelo menos um de uma marca boa sempre a gente compra." 
Vínculos de sentidos: publicidade, marcas e consumo alimentar na vida de famíliar paulistana

de Eneus Trindade

"Por exemplo, o café a gente sempre comprava Nescafé ${ }^{\circledR}$. O Nescafé ${ }^{\circledR}$ tá um pouco mais alto. Aí lançaram um café da marca Qualitá ${ }^{\circledR}$ comprei uma vez, há uns dois meses atrás. A gente achou bem semelhante, não tem quase diferença nenhuma. A gente continuou comprando ele porque ele tá mais barato. Acho que uns $20 \%$ mais barato".

“Açúcar eu prefiro sempre comprar o açúcar União®, mas quando ele tá um pouco mais caro. Eu compro um... Nem sei a marca dos outros pra falar a verdade... Caravella®... É tem opções foi açúcar tá branquinho se o outro tiver muito mais em conta a gente troca também."

"Nescau ${ }^{\circledR}$ também quando Nescau tá caro a gente troca por Toddy® ou por marca do próprio supermercado. Que geralmente bareteia bem quando é a marca do próprio mercado".

"Massa de tomate, Molho de tomate. Molho de tomate é o que tiver mais em conta também. Por exemplo, este mês a gente comprou Salsaretti®. Quando o Pomarolla ${ }^{\circledR}$ tá em promoção, que eu acho que é o melhorzinho, a gente vai de Pomarolla®. Mas, só quando ele tá de promoção. Se não vão outras marcas também.”

"Macarrão. Macarrão qualquer um tá legal... assim, Dona Benta ${ }^{\circledR}$, Adria ${ }^{\circledR}$ não precisa ser aqueles mais caros. Porque os bons mesmo, a massa legal, mais fininha fica assim, tipo, o dobro, três vezes mais caro que os mais em conta."

Os rituais alimentares são seguidos, mas cada um faz os seus horários na casa. Confirma-se a erosão da alimentação doméstica como verificado nas outras famílias observadas, a exemplo da imagem da sala de jantar vazia da classe média a melhor manifestação dessa constatação. Contudo, a visita do entrevistador aconteceu no momento do Café da tarde, sendo este o único registro de um ritual alimentar nas famílias observadas durante a pesquisa.

A dieta deste núcleo segue um cardápio diário simples e parece ser equilibrada. Ou pelo menos, há uma preocupação, por parte dos moradores, sobretudo do filho mais velho (professor de educação física), com relação aos excessos de gorduras na alimentação, como revelam as suas falas.

Boa parte das marcas de alimentos preferidas da família de baixa renda faz parte do universo das marcas citadas nas outras famílias entrevistadas, o que mostra o poder de corporações como a Nestlé, por exemplo, em todos os núcleos visitados pela preferência por marcas como Nescau e Leite Moça. Contudo, as marcas se referem a um universo de marcas rotineiras, diferentemente da classe alta que busca experimentar novos sabores e produtos alimentícios diferentes.

Quanto à interferência da mídia na alimentação, o filho mais velho, ao mesmo tempo, que manifesta uma crítica ao aspecto manipulatório e mentiroso, na sua opinião, sobre a publicidade, ele também se mostra receptivo às mensagens promocionais de alimentos, de modo semelhante à dona da casa da família de classe média, também buscando economizar. Às vezes, no caso específico da família de baixa renda, o entrevistado revela a possibilidade de comprar marcas próprias ou marcas concorrentes, semelhantes e mais baratas para economizar e satifazer necessidades simbólicas de 
Vínculos de sentidos: publicidade, marcas e consumo alimentar na vida de famíliar paulistana

consumo, ao comprar um produto na idealização do consumo sobre outra marca considerada melhor, como no exemplo do panetone.

As compras são feitas por mês, em hirpermercados, preferencialmente no Extra, que é próximo à residência da família e "tem tudo". A alimentação consome boa parte do orçamento familiar, pois os rendimentos dos integrantes da família são baixos. Com isso percebemos que os vinculos-sígnicos-materiais, são também, neste caso, os vínculos sígnicos-simbólicos, pois a impossibilidade de consumo de marcas caras implica nas opções de prazer gustativo, substituindo os produtos por marcas semelhantes mais baratas. Assim, o panetone Bauducco é substituído pela marca Village, o Nescafé pela marca própria Qualitá e assim por diante. Se as condições financeiras fossem outras, certametne eles consumiriam as marcas de suas preferências.

Por fim, outro aspecto a observar é que a família, pelo consumo de produtos de milho e farináceos, mostra suas raízes nordestinas, indicando os traços de uma cultura alimentar fruto de processos migratórios, que demostram como pouco a pouco esses fluxos particulares moldam a oferta dos mercados de alimentos para atender novas demandas que, nesse processo, vão se constituíndo. Assim como acontece no universo da classe alta, os produtos importados também fazem este papel, criando as condições para que o mundo mercantil do sistema alimentar possa se hibiridizar e revelar-se no consumo pela sua pertinência ao universo simbólico das pessoas.

\section{CONSIDERAÇÕES FINAIS}

Nesta opotunidade, buscamos apresentar os vínculos de sentidos entre publicidade, marcas e práticas sociais na cultura de consumo alimentar do universo doméstico. Os limites da observação etnográfica restritos a duas visitas nas casas, não possibilitou um mapeamento regular de todos os rituais alimentares diários, dentro de um rigor etnográfico desejável. Por outro lado, forneceu informações sólidas sobre as participações das marcas e da publicidade no consumo alimentar para o sentido das vidas das famílias estudadas, em função de suas preferências e das condições socioeconômicas que possuem.

O material apresentado ainda é passível de aprofundamentos e percebemos outras perspectivas de abordagens teóricas nos campos da comunicação e da saúde alimentar. No primeiro caso, podemos aboradar os discursos das famílias na perspectiva 
Vínculos de sentidos: publicidade, marcas e consumo alimentar na vida de famíliar paulistana

das lógicas do consumo e de sua crítica, aspecto este que iremos emprender com base na análise de discurso crítica, conforme o trabalho de Norma Fairclough (2001).

No segundo caso, podemos dialogar com o campo da saúde, pois os alimentos registrados nas imagens, por exemplo, suscitam uma classificação dos produtos de acordo com a pirâmide alimentar e sua representação no universo doméstico das famílias. Aqui, não tivemos espaço para explorar este aspecto, que certamente pode trazer novos significados sobre a cultura alimentar doméstica ligando a comunicação e a nutrição.

Sabemos que as proposições aqui colocadas demandam desdobramentos e que certamente ajudarão a enriquecer a discussão aqui iniciada e que procurou valorizar a apresentação dos dados empíricos sitematizados. Isso, ao nosso ver, demonstra a potencialidade do estudos dos vínculos de sentidos na produção de sentido que se constrói entre os usos midiáticos e os consumos da vida material.

Por fim, reconhecemos que os limites de uma investigação qualitativa como esta, impedem generalizações, mas seus resultados configuram um caminho que ajuda a esclarecer as relações culturais de sentidos da enunciação da recepção publicitária, entre os sujeitos, tempos e espaços dos universos domésticos e de seus consumos alimentares específicos.

\section{REFERÊNCIAS BIBLIOGRÁFICAS}

DI NALLO, E. (1999). Meeting Points. Marketing para uma sociedade complexa. São Paulo. Cobra.

FAIRCLOUGH, N. (2001). Discurso e mudança social. Brasília:UNB. Trad. Izabel Magalhães.

McCRACKEN, G. (2003) Cultura e consumo. Novas abordagens ao caráter simbólico dos bens e das atividades de consumo. Rio de Janeiro. Ed. Mauad. Trad. Fernanda Eugênio. Coleção Cultura e Consumo, coordenada por Everardo Rocha.

PIEDRAS, E. R. (2006) As práticas de recepção da publicidade como fluxo: apontamentos teórico-metodológicos. In JACKS, N. et al. O que sabemos sobre as audiências. Porto Alegre: ALAIC GT-Estudios de Recepción/ Ed.Armazém Digital, p. 60-72. 
Vínculos de sentidos: publicidade, marcas e consumo alimentar na vida de famíliar paulistana

de Eneus Trindade

POULAIN, J-P. (2002) Sociologie de l'alimentation. Les mangeurs et l'espace social alimentaire. Paris. PUF.

TRINDADE, E. (2008a) Diretrizes para uma teoria da enunciação da recepção publicitária. INTERCOM - Revista Brasileira de Ciências da Comunicação. São Paulo: INTERCOM. v.31. n. 2. jul-dez. p.35-54.

. (2008b) Recepção publicitária e práticas de consumo. Revista Fronteiras. Estudos Midiáticos. São Leopoldo: Unisinos. v. X. n.11.p.73-80.

; (2009) Da etnografia à produção de sentido da recepção publicitária e das práticas de consumo na vida social. Animus-Revista Interamericana de Comunicação midiática. Santa Maria: UFSM. v.15,n.1. p.1-15. http://www.ufms.br/animus/animus_2009_art07.html

; MOREIRA, R. A. L. (2009) A produção de sentido do consumo no universo familiar paulista. XXXII Congresso Brasileiro de Ciências da Comunicação. Curitiba: INTERCOM/Universidade Positivo. GP - Publicidade e Propaganda. $1^{\circ}$ CD-Rom.

Artigo recebido: 10/07/2010

Artigo Aprovado: 30/09/2010 